\title{
BREADCRUMBS FOR AN ALIEN
}

\author{
Missed connections.
}

\section{BY BO BALDER}

$\mathrm{O}$ ne of the aliens was still alive. We had watched the fire streaking down from the sky and the egg smash down. As soon as the egg cooled down a bit, we had gathered on the site to find out what it was. Our party was about to enter the broken egg when we saw movement, and prudently waited for the aliens to emerge from the egg. Or to offer help if they couldn't.

Something scurried out, almost too fast for us to see. A bipedal creature with a bulbous shiny eye on top. As we stared, trying to get a grip on its movements, it skittered hither and yon, standing still and scanning the horizon for no more than a pharynx beat before hurrying off again. In and out it went, stacking what seemed to be provisions for a journey. We couldn't be sure at that distance. It covered the heap of squishy stuff with rocks and bound two sticks crosswise on top of it.

Then it became humpbacked and started walking off in its peculiar, unsteady gait. Where was it going, we wondered. What destination could it have on our home? Maybe it would visit our humble village and share tales of its faraway, exotic home with us. We speculated on its purpose even as we debated what to do next. Some of us would follow, it was decided, in case it needed help or company. It seemed so forlorn as it speed-stumbled with its thin, kinked limbs.

Some of us went to have a peek at the egg, which it had left open, and its stack of provender. The stack turned out to contain members of its own race. The white outer skin had been peeled and the eye-bulbs taken off, leaving rather a mess. How odd not to consume one's family after they died. But perhaps the alien still had a ritual to per-

ONATURE.COM Follow Futures: @ @ NatureFutures 7 go.nature.com/mtoodm form before it could fulfil this honourable function?

The egg was badly damaged. It would not be able to leave our planet in its present state. Our curiosity fulfilled, we hastened after the creature on its puzzling journey.

We badly wanted to talk to it, ask it questions about the outer world and its place of origin. We reasoned it had to be intelligent,

poor blind, clumsy creature.

When dawn came, the alien lay immobile and curled up. It had died during the night. A wonderful opportunity to take a closer look before it pulped like its fellows. The stick-like limbs, the delicate sensors at the end fascinated us. The bulbous eye on top had mysterious blotches in its depths. Some of us tapped the eye and it rang out in the quiet morning. We scrambled off, startled, only to discover that the alien had come back to life and had moved even faster than we had. We ran after it, rejoicing in the game, only to find that we were again invisible.

We were very disappointed: but you know how it is, we had our own lives to live, duties to perform, spawn to raise. Occasionally, we would still see the alien wear a pathway between its broken egg and the beach. Did I imagine it or was it starting to move more slowly?

What did it want? What did it dream of? If only we could communicate. We would love so dearly to help the lonesome creature, who had no one to share lichen

to fashion a travelling egg and to perform a strange but clearly deliberate act on its fellows.

And also we imagined how sad we would be if our fellows had ended and we were all alone on a strange world. How in need of solace we would be!

It was quite the experience. The alien didn't seem to see the roadways laid out so neatly over the plateau and found opportunity to stumble and fall in every crevice or pool. It stepped on our lichen fields, lumbered through settlements, its course wavering all over the place. Eventually, it reached the ocean. It stared at the surf rolling in and back out, its sadness palpable to anyone with a beating pharynx.

We got weary of observing it and tried to make contact, to offer condolences. But it didn't react at all. As if it didn't see us. We stepped on the path and waited for it. It managed to walk right around us. We carved signs and sigils and laid out food, to no avail, or speech with.

The year wore on and we had a bit more pharynx to spare away from our spawn. We copied the markings on the alien egg in fastgrowing lichen on the rock. Year's end was near when we finished the project.

The alien was resting near the markings, its small sensor near the first marker.

We waited a very long time, but we fear the alien has ended.

It's a great comfort that it knew it was not alone before it ended, although we wish more communication had been possible. Hopefully, the next aliens to visit us will be a little bit more astute.

Bo Balder lives and works close to Amsterdam. She is the first Dutch author to have been published in F\&SF, Clarkesworld and Analog. Her science-fiction novel The Wan was published by Pink Narcissus Press. For more about her work, you can visit her website or find her on Facebook. 